\title{
АКТУАЛЬНЫЕ ПРОБЛЕМЫ ОСУЩЕСТВЛЕНИЯ ЭЛЕКТРОННОГО ПРАВОСУДИЯ В РОССИИ
}

\author{
(c) 2019 Лошкарев Андрей Викторович \\ кандидат юридических наук \\ Самарский государственный экономический университет, Россия, Самара \\ E-mail:2482337@mail.ru \\ (c) 2019 Кириллова Алина Алишеровна \\ студент-магистрант \\ Самарский государственный экономический университет, Россия, Самара \\ E-mail: alina.kirillova.96@bk.ru
}

В связи с развитием в российском государстве информационных технологий, их модернизации, одной из значимых на сегодняшний день является проблема осуществления электронного правосудия. В статье выделяются особенности осуществления правосудия в России при помощи информационных технологий, а также анализируется зарубежный опыт применения законодательства по данному вопросу. В совокупности определяются положительные и отрицательные аспекты осуществления электронного правосудия, проводится анализ реформирования российской судебной системы путем внедрения цифровых технологий, позволяющих осуществлять доступ граждан к правосудию.

Ключевые слова: электронное правосудие, гражданский процесс, судебная власть, информатизация судов, аудиопротоколирование, информационные технологии.

Актуальным на сегодняшний день является вопрос, касающийся темы электронного правосудия, поскольку государство на сегодняшний день претерпевает изменения в сфере информационных технологий, наблюдается значительное усовершенствование в данной области.

Развитие электронного правосудия является важным аспектом, поскольку совершенствует в целом всю судебную систему и позволяет осуществить ее переход на новый, модернизированный уровень. Необходимость в этом существует не только у лиц, юридически заинтересованных, но и всех лиц в целом, так как практически невозможно в современных реалиях избежать столкновения с аппаратом судебной власти.

Становление в России электронного правосудия является вполне обоснованным, учитывая демократический строй государства, который требует прозрачности деятельности всех ветвей судебной власти, в том числе и судебной.

Термин «электронное правосудие» на сегодняшний день определяется в различных интерпретациях в зависимости от теоретических и практических знаниях, полученной в данной области.

Под электронным правосудием, в частности, понимают применение информационно- коммуникационных технологий в осуществлении правосудия всеми заинтересованными сторонами в сфере юриспруденции, для повышения эффективности и качества государственных служб, в том числе, для частных лиц и предприятий [1]. Данное определение предполагает, что электронное правосудие осуществляется в интересах граждан и рассматривается, прежде всего, для улучшения качества работы государственного аппарата.

С целью осуществления электронного правосудия требуется создание нормативного блока для регламентирования действий по переводу документов в цифровой формат, достаточным образом проработать особенности цифровой среды, а также проанализировать иные, заслуживающие внимания аспекты.

Электронное правосудие позволяет продемонстрировать общественности деятельность судебной системы, ее прозрачность, от этого зависит и предупреждение коррупционных проявлений, возможно при этом сформировать у граждан доверие к российской судебной системе. Все эти факторы нашли свое развитие в Концепции федеральной целевой программы «Развитие судебной системы России на 2013-2020 годы», утвержденной Распоряжением Прави- 
тельства Российской Федерации от 20 сентября 2012 года № 1735 -р.

На данный момент существует Концепция информационной политики судебной системы на 2020-2030 годы», согласно которой информационная политика должна быть частью общей стратегии развития судов. Популяризация знаний о судебной системе повышает имидж суда, расширяет возможности профориентации, является действенным инструментом для расширения кругозора в области судебной деятельности среди широкой общественности [2].

Концепция в такой интерпретации определяет, что информационная политика, выступающая частью судебной системы, позволит общественности более доступно и прозрачно понять всю суть судебной деятельности.

Законодатель также полагает, что осуществление электронного правосудия существенным образом влияет на развитие всей судебной системы в целом, от уровня информационной оснащенности какой-либо сферы зависит показатель ее продуктивности.

Вообще электронная среда выступает мощным регулятором для современного общества, без информационных технологий не обходится ни одна сфера жизнедеятельности.

Осуществление электронного правосудия на данном этапе общества более развито, к примеру, производится подача документов в суд в электронном виде (на электронную почту суда либо через систему ГАС «Правосудие»), извещение сторон происходит посредством SMSоповещения, проводятся видеоконференц-связь. Техническая оснащенность суда в таком случае позволяет участникам процесса реализовать свое право на открытое, всестороннее и объективное рассмотрение дела.

Однако при указанных возможностях существует и ряд проблем осуществления электронного правосудия, которые затрудняют работу судебной системы и в целом доступ граждан к правосудию. В этой связи предполагается провести сравнительный анализ отечественного и зарубежного опыта осуществления электронного правосудия.

В зарубежной практике при осуществлении электронного правосудия, суды пользуются различными платформами, которые позволяют повысить эффективность их работы.

Так, в Германии суды осуществляют свою работу при помощи системы EGVP, которая обеспечивает обмен правовой информацией между населением и государственным аппаратом [3]. Данная система обеспечивает возможность гражданам осуществлять круглосуточный доступ к информационным судебным ресурсам, предоставляет надежную передачу данных, защищенная связь с использованием криптографических механизмов, возможность электронной обработки файлов, получение автоматических уведомлении по электронной почте, поддержка всех аккредитованных карточек подписи.

Электронное правосудие осуществляется с акцентом на конфиденциальности личных данных, поскольку в Германии в большинстве случаев лицо не может представлять в суде свои интересы без участия в процессе адвоката. В связи с этим, электронный документ, который передается через систему электронного правосудия, зафиксирован на таком носителе, что может считываться только при помощи специальных технических устройств. Соответственно, устанавливаются и специальные технические требования, которым должны удовлетворять электронные документы. Стоит отметить, что с такими требованиями могут ознакомиться только специально допущенные адвокаты.

В США используется система «Управление делом/электронный реестр дел (СМ/ЕСF»), которая предназначена для электронной подачи документов. Особенность системы заключается в том, что она предупреждает пользователей об ответственности за раскрытие конфиденциальной информации, кроме того, система требует дать согласие на добросовестное использование предоставленной информации. Следует также отметить, что США является основоположником идеи электронного правительства.

Особенностью осуществления электронного правосудия в США является также наличие в ней учебно-методических пособий по использованию системы, которые позволяют обеспечить доступ к электронному правосудию не только для юристов, обладающих специальными познаниями в данной сфере, но и для граждан, никогда ранее не взаимодействующих с указанной системой.

Зарубежный опыт позволяет сделать вывод, что для осуществления электронного правосудия необходимо соблюдать, прежде всего, конфиденциальность предоставляемых данных, учесть техническую и теоретическую оснащен- 
ность общества при пользовании данной системой.

Стоит при этом отметить, что электронное правосудие развивается в России достаточно эффективно, государство идет в ногу с большинством развитых правопорядков. Несмотря на имеющийся зарубежный опыт, учитывая различную специфику осуществления государственной власти, возможности государственного аппарата действовать в соответствии с принятыми нормами и правилами, российское государство имеет достаточную нормативную и теоретическую базу для осуществления электронного правосудия. Естественно, для поддержания данного уровня, у государства периодически возникает потребность в применении нововведений.

Подтверждением данной гипотезы может послужить введение в ГПК РФ ряд изменений, которые затрагивают информационную сферу. Так, с 01.09.2019 г. законом предусмотрено обязательное аудиопротоколирование судебных заседаний, которое предусматривает наряду с протоколом в письменной форме ведение и протокола при помощи аудиозаписи. Внедрение аудиопротоколирования позволяет обеспечить гражданам открытость и прозрачность осуществляемого правосудия, позволяет вышестоящей инстанции проанализировать все обстоятельства дела и проверить законность и обоснованность вынесенного решения.

Помимо всего прочего, данное нововведение позволяет также предупредить ряд коррупционных проявлений, а также сформировать доверие граждан к российской судебной системе.

Однако, в этом аспекте возникает и ряд проблем, таких как отсутствие технической возможности, достаточной технической оснащенности судов для ведения аудиопротоколирования, отсутствие специально отведенных комнат для прослушивания аудиозаписей. Несомненно, что в данной, как в любой другой сфере, при модернизации имеющегося уровня возникает ряд проблем, которые в дальнейшем являются предметом дискуссий многих ученых. Однако это служит лишь положительным фактором, позволяющим в должной мере урегулировать данный вопрос.

Предполагается, что суды общей юрисдикции с момента подписания Федерального Закона от 29.07.2018 № 265-ФЗ и вступления его в силу должны быть оснащены соответствующими техническими средствами с исправными системами звукозаписи и должны обеспечивать сохранение файлов в информационной системе суда [4].

Думается, что при введении новых норм, регулирующих осуществление электронного правосудия необходимо сопоставлять возможности программного обеспечения с установленными стандартами. Первоначально разработчики программного обеспечения должны демонстрировать готовность к внедрению нововведений, после чего такие нормы принимаются на законодательном уровне [5].

Помимо указанных проблем, существует также проблема обеспечения информационной безопасности, которая вытекает из проводимой информационной политики. Персональные данные обладают особой ценностью, поскольку в них содержится информация о личных данных человека, которые не подлежат распространению.

Думается, что необходимо найти баланс между реализацией принципа информационной открытости деятельности судов и применением мер защиты в информационной сфере.

Анализ проблем осуществления электронного правосудия в гражданском процессе позволяет прийти к выводу, что на сегодняшний день, Россия находится на стадии совершенствования информационного пространства. Безусловно, с развитием новых информационных технологий появляются и новые платформы для осуществления электронного правосудия, открываются иные возможности его реализации.

Осуществление электронного правосудия включает в себя аспекты не только технической, но и теоретической оснащенности. В частности, целесообразным будет являться проведение различных региональных программ для внедрения и развития определенных образовательных стандартов в данной области.

Следует отметить, что электронное правосудие не призвано решать классические проблемы, оно предназначено для эффективного функционирования деятельности судов с точки зрения технической оснащенности судов. Следовательно, цифровая трансформация выступает одним из элементов судебной системы, которая призвана находится попутно с решением имеющихся глобальных проблем. 


\section{Библиографический список}

1. Рекомендации Комитета министров Совета Европы N CM/Rec (2009) 1 государствам - участникам Совета Европы по электронной демократии (приняты 18.02.2009 на 1049-м собрании заместителей министров). [Электронный ресурс].- Режим доступа: http://cikrf.ru/international/recommend.doc.

2. Концепция информационной политики судебной системы на 2020-2030 годы (одобрена Советом судей РФ) [Электронный ресурс].- Режим доступа: http://www.ssrf.ru.

3. Муромская Ю.В., Батурина Н. А. Электронная форма судопроизводства за рубежом // Инновационная наука. - 2019. - № 4.- С.136-140.

4. Федеральный закон от 29 июля 2018 г. № 265-ФЗ «О внесении изменений в отдельные законодательные акты Российской Федерации» [Электронный ресурс] // Справочная правовая система «КонсультантПлюс».

5. Борисова В.Ф. Реализация конституционного права на судебную защиту в аспекте применения электронных технологий // Администратор суда.-2019. - № 2.- С. 9-12. 